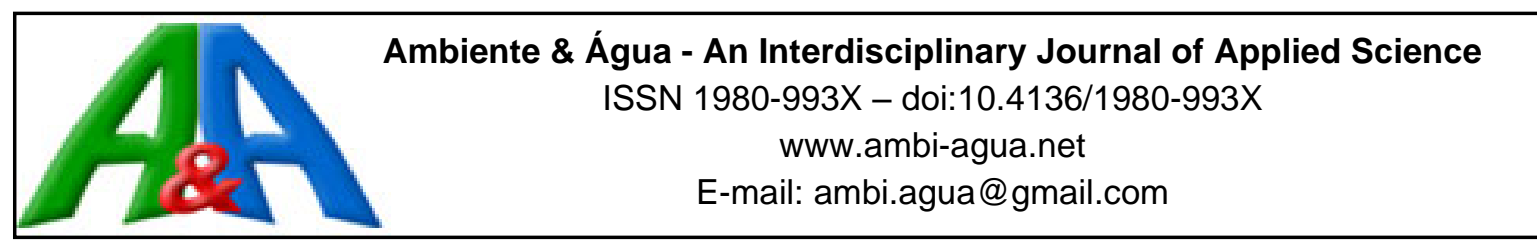

\title{
Evaluation of hydrogel use in the development of Rapanea ferruginea with water restriction by vibrational Fourier Transform Infrared Spectroscopy (FTIR-UATR)
}

\author{
ARTICLES doi:10.4136/ambi-agua.2744
}

Received: 03 May 2021; Accepted: 17 Aug. 2021

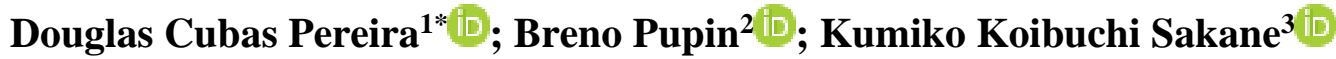

${ }^{1}$ Instituto de Pesquisa e Desenvolvimento. Laboratório de Espectroscopia Vibracional no Infravermelho. Universidade do Vale do Paraíba (UNIVAP), Avenida Shishima Hifumi, n 2911, CEP: 12244-000, São José dos Campos, SP, Brazil.

${ }^{2}$ Centro de Ciência do Sistema Terrestre. Instituto Nacional de Pesquisas Espaciais (INPE), Avenida dos Astronautas, $\mathrm{n}^{\circ}$ 1758, CEP: 12227-010, São José dos Campos, SP, Brazil. E-mail: breno0891@ @otmail.com ${ }^{3}$ Instituto de Pesquisa \& Desenvolvimento. Faculdade de Engenharias, Arquitetura e Urbanismo. Universidade do Vale do Paraíba (UNIVAP), Avenida Shishima Hifumi, n 2911, CEP: 12244-390, São José dos Campos,

SP, Brazil. E-mail: kumiko@univap.br

*Corresponding author. E-mail: douglas.cubas@hotmail.com
\end{abstract}

\begin{abstract}
This study evaluated the use of hydrogel on the development of Rapanea ferruginea under water restriction through Vibrational Fourier Transform Infrared Spectroscopy (FTIR-UATR). Seedlings of approximately $30 \mathrm{~cm}$ height were transferred in pots with $3 \mathrm{~L}$ of soil. The group of seedlings was separated into 5 different triplicate treatments according to the amount of hydrogel, as follows: H1 (25\%), H2 (20\%), H3 (15\%), H4 (10\%) and S (control without hydrogel). The applied hydrogel was mixed homogeneously with the soil. All treatments were irrigated with $40 \mathrm{~mL}$ of water. FTIR spectra were obtained from fresh leaves collected during 13 months of monitoring. The correlation of the hydroxyl (water) band with the main biomolecules between treatments with the control was evaluated using the Mann-Whitney test ( $\mathrm{p}<0.05)$. The biomolecule bands were subjected to principal component analysis (PCA) and hierarchical clustering analysis (HCA). The results indicate a significant correlation of the water band with the lipid, hemicellulose, cell wall and starch components in the species. The use of hydrogel resulted in a significant difference in the water absorption band in relation to the control group through the Mann-Whitney test and in biomolecules as the HCA and PCA analysis suggested. The best development was observed in groups H4 (10\%), H2 (20\%) and H3 $(15 \%)$. The use of hydrogel positively influences the biomolecular development of the Rapanea ferruginea and monitoring is viable by FTIR.
\end{abstract}

Keywords: FTIR infrared spectroscopy, plant water management, superabsorbent polymer.

\section{Avaliação do uso de hidrogel no desenvolvimento da Rapanea ferruginea com restrição hídrica por espectroscopia vibracional no infravermelho médio com transformada de Fourier (FTIR-UATR)}

\section{RESUMO}

Objetivou-se avaliar a influência do uso de hidrogel sobre o desenvolvimento da Rapanea

This is an Open Access article distributed under the terms of the Creative Commons Attribution License, which permits unrestricted use, distribution, and reproduction in any medium, provided the original work is properly cited. 
ferruginea sob restrição hídrica por meio da técnica de Espectroscopia Vibracional no Infravermelho Médio com Transformada de Fourier (FTIR-UATR). As mudas com aproximadamente $30 \mathrm{~cm}$ de altura foram transferidas em vasos com $3 \mathrm{~L}$ de solo. $\mathrm{O}$ grupo de mudas foi separado em 5 tratamentos distintos em triplicata de acordo com a quantidade de hidrogel, sendo: H1 (25\%), H2 (20\%), H3 (15\%), H4 (10\%) e S (controle sem hidrogel). O hidrogel aplicado foi misturado de forma homogênea ao solo. Todos tratamentos foram irrigados diariamente com $40 \mathrm{~mL}$ de água. Os espectros FTIR foram obtidos das folhas in natura coletadas por 13 meses de monitoramento. Foi avaliada a correlação da banda de hidroxila (água) com as principais biomoléculas e as diferenças existentes entre os tratamentos com o controle por meio do Teste de Mann-Whitney $(\mathrm{p}<0,05)$. As bandas das biomoléculas foram submetidas a análise de componentes principais (PCA) e análise hierárquica de agrupamento (HCA). Os resultados indicam uma correlação significativa da banda de água com os componentes lipídios, hemicelulose, parede celular e amido na espécie. O uso do hidrogel proporcionou diferença significativa na banda de absorção de água em relação ao grupo controle por meio do Teste de Mann-Whitney e nas biomoléculas como a análise de HCA e PCA sugeriu. O melhor desenvolvimento foi observado nos grupos H4 (10\%), H2 (20\%) e H3 (15\%). O uso do hidrogel influencia positivamente no desenvolvimento biomolecular da Rapanea ferruginea e o monitoramento é viável por FTIR.

Palavras-chave: espectroscopia no infravermelho FTIR, manejo hídrico de plantas, polímero superabsorvente.

\section{INTRODUCTION}

Natural ecosystem degradation is mainly caused by undue anthropic practices such as the scarcity of planning in occupation together with the lack of adequate management which leads to deforestation with consequent accelerated soil degradation and plant biodiversity loss (Fragoso et al., 2016). Mostly, the ecosystem loses its resilience capacity and in order to reverse the degradation processes, direct anthropic intervention such as the planting of native seedlings is necessary (Ferraz and Engel, 2011).

Rapanea ferruginea, popularly known as Capororoca-Vermelha, is a pioneer mediumsized tree species (6-12 m) found in Brazilian biomes, especially in the Atlantic Rain Forest. It is widely used in the recovery of degraded areas due to its resistance and high reproducibility in impacted soils with low levels of nutrients such as sandy soils (Lorenzi, 2008). That species is important in secondary ecological succession, the fruits attract avifauna which propagate other species seeds and stimulate recovery (Pascotto, 2007).

Higher plants are directly affected by several external factors such as the presence of nutrients, radiation incidence and water (Larcher, 2000). Irrigation is essential because it is responsible for the transport of nutrients. Water stress is the main cause of the failure of environmental recovery processes in degraded areas and in silvicultural practices (Sarvas et al., 2007; Mudhaganyi et al., 2016; Felippe et al., 2021).

To overcome the difficulties imposed by irrigation in seedling planting, the use of hydrogels is highlighted to supply water-stressed plants (Mudhanganyi et al., 2016. LinaresGabriel et al., 2018). According to Ramirez et al. (2016) hydrogels are hydrophilic polymeric materials obtained from the polyacrylonitrile polymerization consisting of a three-dimensional linear chain network which allows high water absorption reaching 400 to $1500 \mathrm{~g}$ of water per dry gram (Sloan, 1994; Koupai et al., 2008).

The assessment of hydrogels use in planting is traditionally conducted by monitoring the effect on plant height, mass (leaves and roots) and the soil's retention capacity (Mews et al., 2015; Mudhaganyi et al., 2016; Linares-Gabriel et al., 2018; Felippe et al., 2021). However, 
little has been studied about the influence on the plants biomolecular development using modern techniques such as Fourier Transform Infrared Spectroscopy (FTIR-UATR), which arises from evaluating atomic vibrations of the molecules that interact with infrared radiation $\left(10^{-6}\right.$ to $\left.10^{-3} \mathrm{~m}\right)$ that depends on molecular structure (Pavia et al., 2010).

The infrared range on the electromagnetic field corresponds to the molecules' vibration energy. The functional groups vibrations corresponding to proteins, polysaccharides, lipids and water are characterized. The vibrations which show the variations in dipole moment are observed in the infrared spectra (Stuart, 2004). FTIR is becoming more common in biological analysis because it is fast, simple, requires small material quantities, is economic, does not destroy the sample, needs little or no sample treatment and doesn't produce residues since no reagents are required (Depciuch et al., 2017).

A sample in any state can be studied: liquids, solutions, pastes, powders, films and gases can be examined by a choice of sampling technique. This versatility allows application in many different research fields, such as soil organic analysis (Heller et al., 2015), effect of toxic soils on plant development (Palacio et al., 2014), air pollution effects on plant pollen (Depciuch et al., 2017), maize crop evaluation (Dokken and Davies, 2007), food sciences (GallardoVelázquez et al., 2009; Kasim et al., 2014; Durazzo et al., 2018; Lucarini et al., 2020), plastic degradation on environment (Ioakeimidis et al., 2016; Chen et al., 2021), human body-fluid analysis (Kochan et al., 2021; Vieira et al., 2021), cell-component analysis (Mihoubi et al., 2017; Güler et al., 2018) and microorganism analysis (Sakane et al., 2021).

Therefore, the present work evaluates hydrogel influence on the biomolecular development of the Brazilian pioneer tree Rapanea ferruginea through the FTIR infrared spectroscopy technique, especially in monitoring the correlation of water presence with the main biomolecular structures.

\section{MATERIALS AND METHODS}

The seedlings were grown in a greenhouse at the Universidade do Vale do Paraíba and transferred to the experimental site located at coordinates $23^{\circ} 24^{\prime} 18.72$ ' $\mathrm{S}$ and $46^{\circ} 3^{\prime} 44.67^{\prime \prime} \mathrm{O}$ with an approximate altitude of 580 meters above sea level. The municipality of Guararema (São Paulo) is classified as hot and temperate - humid subtropical (Cfa) according to the Köppen classification, with an average annual precipitation of $1500 \mathrm{~mm}$ and average annual temperature of $19.7^{\circ} \mathrm{C}$.

\subsection{Hydrogel and Soil Preparation}

The hydrogel used in the seedlings of the evaluated groups was prepared with a $1 \%$ mixture by adding 60 grams of superabsorbent polymer in a volume of 6 liters of water $(10 \mathrm{~g} \mathrm{~L}-1)$, several studies present different techniques such as the dry polymer application, previous hydrogel preparation and variations to the amount applied (Sousa et al., 2013; Mews et al., 2015; Navroski et al., 2016; Cardoso, 2017), in this experiment, the hydrogel was prepared before application. The soil was collected at the experimental site in the organic horizon with $30 \mathrm{~cm}$ depth. The substrate was prepared with a mixture of $25 \%$ tanned bovine manure in relation to the soil mass used for all the seedlings evaluated.

\subsection{Experiment Assembly}

The seedlings were selected after the external physiological conditions evaluation of the specimens. The $30 \mathrm{~cm}$ tall seedlings were transferred to polyethylene pots with a capacity of 3 L. The 15 seedlings were divided in 4 quantities of hydrogel in triplicate plus the control group. The specific mass of the hydrogel used presented the value of $1.0073 \mathrm{~g} \mathrm{~cm}^{3}-1$ the mass of $1 \mathrm{Kg}$ of hydrogel equals $1 \mathrm{~L}$. Therefore, the amount of hydrogel applied in each of the treatments used were: $\mathrm{H} 1=750 \mathrm{~g}(25 \%), \mathrm{H} 2=600 \mathrm{~g}, \mathrm{H} 3=450 \mathrm{~g}$ and $\mathrm{H} 4=300 \mathrm{~g}$ and $\mathrm{S}=$ without hydrogel. 
The dried soil was homogeneously mixed with the hydrogel, the soil was not saturated before application. The amount of hydrogel used was greater and the analysis did not focus on the evaluation of the soil's retention capacity as already addressed in previous research (Felippe et al., 2021). Irrigation was kept constant at $40 \mathrm{~mL}$ per day for all treatments. Even considering the water stress conditions of the experiment, it is necessary to carry out controlled irrigation because the hydrogel can absorb the moisture from the roots in extreme dry substrate and cause a negative impact on plant growth (Bogarim, 2014).

\subsection{Sample Collection for FTIR Analysis}

The seedlings were monitored from September 2019 to September 2020 (13 months), until reaching the growth limit under the controlled conditions. To select the leaves for FTIR analysis, phytosanitary conditions and leaves ageing were observed. Accordingly, young leaves were disregarded for analysis as well as leaves with bad conditions (Lins, 2017). The leaves were collected from the superior seedlings region, where they were cut off with the petioles near the stalk (Durak and Depciuch, 2020).

Samples collected monthly were stored in isolated plastic bags at low temperature to preserve the chemical leaves composition until the analysis (Durak and Depciuch, 2020). The collections were made in triplicate $(n=3)$ for the average and standard deviation evaluation. More intense collections could cause negative impacts on the seedlings.

\subsection{FTIR Spectra Preparation}

The leaves were analyzed in natura in order to assess chemical response close to the natural environment (Buitrago et al., 2018). To monitor plant chemical components more accurately, it is important to avoid sample processing (Durak and Depciuch, 2020). The leaf surface was cleaned with pure methyl alcohol to improve the sample contact with the equipment; residues can prevent the best signal in the spectroscopy analysis (Pavia et al., 2010).

According to previous studies of the species (Lins, 2017), the leaves were pressed abaxially on the ATR diamond crystal by pressure gauges. The spectra were obtained from three delimited points on the abaxial part of the leaf (Figure 1).

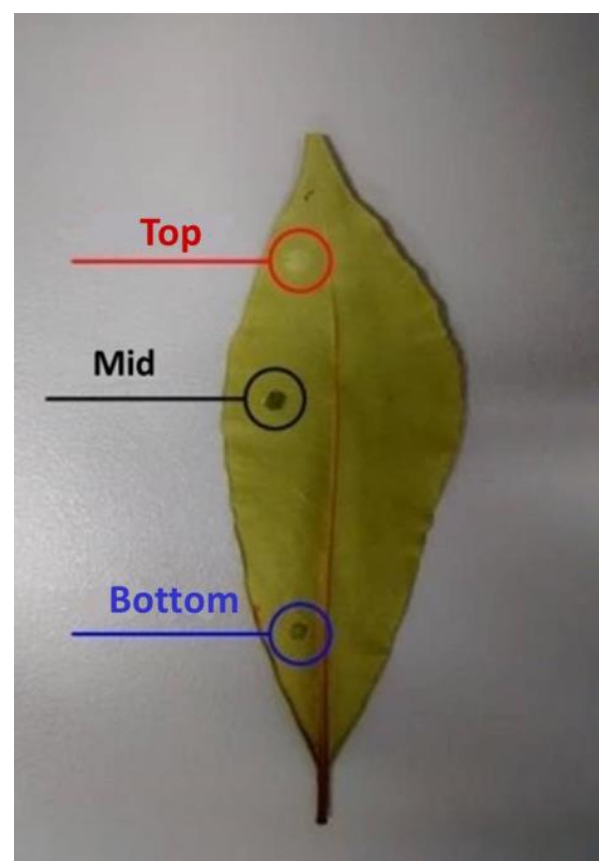

Figure 1. Abaxial collected points on the leaf surface. 
The 585 spectra were obtained in the mid-infrared (MIR) range from $4000 \mathrm{~cm}^{-1}$ to $450 \mathrm{~cm}^{-1}$ at a resolution of $4 \mathrm{~cm}^{-1}$ and 32 scans at room temperature in the spectrophotometer Spectrum Two with Fourier-transform (FTIR) and attenuated reflectance technology (ATR) from PerkinElmer. All spectra were processed by the Spectrum 5.3 software, using baseline corrections, spectral smooth with the Savitsky Golay algorithm (9 points), normalization and absorbance plotting.

The normalization step is important to allow statistical comparison of all spectra. Through the evaluation of the obtained spectra, it was noted that the range from $1680 \mathrm{~cm}^{-1}$ to $1620 \mathrm{~cm}^{-1}$ showed the least variation. This range corresponds to the protein composition (Amide I), which is widely used in the evaluation organic samples (Berthomieu and Hienerwadel, 2009). Thus, this range was adopted for the spectra normalization.

\subsection{Statistical Analysis}

The infrared spectrum bands are related to the chemical bonds present in the plant structure which permit indirect quantification of biomolecule concentrations (Kasim et al., 2014). Statistical data were obtained by calculating the spectra integrated intensity (area) bands corresponding to the vibrational modes of the biomolecular components in the Spectrum 5.3 software. The spectra obtained for every treatment including its standard deviations were plotted on software Origin 8.5. Figure 2 shows the area of the lipids in $3000 \mathrm{~cm}^{-1}$ to $2800 \mathrm{~cm}^{-1}$.

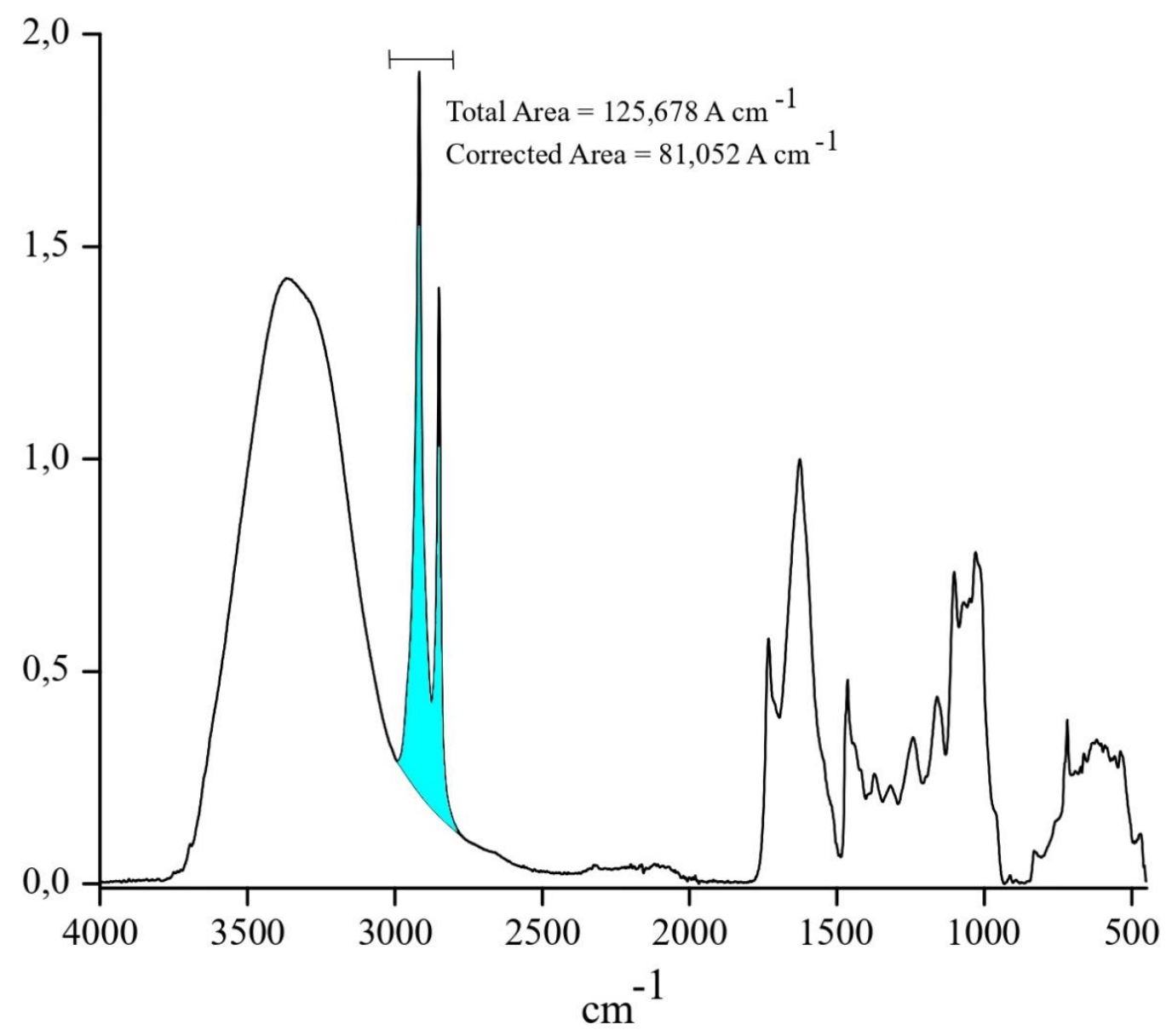

Figure 2. Example of lipids area calculated on Spectrum 5.3 software.

The spectra area data were processed in the Spectrum 5.3 and MiniTab 17 softwares. The band ranges correspond to the lipids $\left(3000 \mathrm{~cm}^{-1}-2800 \mathrm{~cm}^{-1}\right)$ and to the fingerprint components region $\left(1770 \mathrm{~cm}^{-1}-700 \mathrm{~cm}^{-1}\right)$, where the largest amounts of assessed biomolecules are located, were subjected to principal component analysis (Principal Component Analysis - PCA) and 
techniques of hierarchical clustering analysis (HCA). The matrices obtained were evaluated by HCA analysis to observe the biomolecular differences between seedlings with hydrogel and without.

The band range corresponding to the water in the FTIR was subjected to the normality test to observe the type of distribution. From this evaluation the non-parametric hypothesis test for non-normal samples (Mann-Whitney Test - U) was performed to observe differences $(p<0,05)$ between treatments and control.

The R software was also used to verify which biomolecules showed the most significant Pearson correlation with the water band in each treatment in order to observe which biomolecules were most influenced by hydrogel use in the Rapanea ferruginea.

\section{RESULTS AND DISCUSSION}

\subsection{Correlation - Biomolecules $\mathrm{x}$ Water}

The use of hydrogel in plant development is addressed in several studies that demonstrate the positive impact on nutrient absorption and substrate use (Navroski et al., 2016); the application has been expanding in the planting of native Brazilian species for reforestation (Mews et al., 2015) as well as in the species of commercial interest (Linares-Gabriel et al., 2018; Felippe et al., 2021).

Water availability is crucial for plant growth, which allows nutrient absorption and transport in the processes of cellular development and in the photosynthetic capacity (Larcher, 2000). The spectroscopic techniques allow the quantification of biomolecular constituents of plants under external factors, such as water stress (Buitrago et al., 2016).

Rapanea ferruginea seedlings cultivated with different amounts of hydrogel were evaluated in comparison to control seedlings. As the focus of the present evaluation is the water influence provided by hydrogel on the biomolecular structure, the Pearson correlation between the band corresponding to the water and the main biomolecules was calculated. Using linear regression analysis by the least square method through $\mathrm{R}$ software (Table 1).

Table 1. Pearson correlation: water band (3700-3000) x main biomolecules (H x S).

\begin{tabular}{|c|c|c|c|c|c|c|c|}
\hline Groups & $\begin{array}{c}\mathrm{H}_{2} \mathrm{O} \\
\mathbf{x} \\
\text { Chlorophyll }\end{array}$ & $\begin{array}{c}\mathrm{H}_{2} \mathrm{O} \\
x \\
\text { Lignin }\end{array}$ & $\begin{array}{c}\mathrm{H}_{2} \mathrm{O} \\
\mathbf{x} \\
\text { Hemicellulose }\end{array}$ & $\begin{array}{c}\mathrm{H}_{2} \mathrm{O} \\
\mathrm{x} \\
\text { Starch }\end{array}$ & $\begin{array}{c}\mathrm{H}_{2} \mathrm{O} \\
\mathbf{x} \\
\text { Pectin }\end{array}$ & $\begin{array}{c}\mathrm{H}_{2} \mathrm{O} \\
\mathbf{x} \\
\text { Lipids }\end{array}$ & $\begin{array}{c}\mathrm{H}_{2} \mathrm{O} \\
\mathbf{x} \\
\text { Cellulose }\end{array}$ \\
\hline H1 x S & -0.45 & -0.20 & $-0.81 *$ & $-0.75^{*}$ & -0.66 & $-0.76^{*}$ & $-0.70 *$ \\
\hline $\mathrm{H} 2 \times \mathrm{S}$ & -0.37 & -0.13 & $-0.78 *$ & $-0.76^{*}$ & $-0.72 *$ & $-0.81^{*}$ & $-0.74 *$ \\
\hline$H 3 \times S$ & -0.35 & -0.14 & $-0.79 *$ & $-0.78^{*}$ & -0.69 & $-0.77^{*}$ & $-0.79 *$ \\
\hline H4 $\times S$ & -0.40 & -0.20 & $-0.74 *$ & $-0.77^{*}$ & -0.66 & $-0.80^{*}$ & $-0.74 *$ \\
\hline
\end{tabular}

*Significantly strong autocorrelation values.

The Pearson correlation evaluation is important to observe which biomolecules have a linear behavior in relation to the water band. The Pearson correlation values were generated with the bands areas calculated. The values oscillate between -1 and 1 , the closer to the extremities the stronger the correlation (Larson and Faber, 2010). The results obtained indicate that the correlation between the water band with the biomolecules was inversely proportional, a phenomenon expected, considering that in the plant tissue-development process, the absorbed water decreases because it is consumed (Larcher, 2000).

The linearity parameter is an important validation method for FTIR analysis. The low 
correlation of chlorophyll in relation to water may be related to the spectrophotometer midinfrared detection limit proximity, as was also noted with the lignin band (Stuart, 2004). Chlorophyll is related to the water availability (Larcher, 2000). Therefore, future studies with the chlorophyll band assessment are necessary. Bands that showed the highest correlations between hydrogel treated and control seedlings were, respectively, lipids, hemicellulose, starch and cellulose. Due to its high intensity, which allows a better quantification, the lipid band stands out as important for the evaluation of plants by FTIR (Kasim, 2014). H2 group (20\% hydrogel) stood out with the best correlation performance.

\subsection{Mann-Whitney test (U)}

The spectra water bands were submitted to normality assessment, the results obtained indicated that the data distribution was non-normal. Thus, it was necessary to use the nonparametric Mann-Whitney (U) test to observe the differences between the hydrogel treatments in relation to the control group in the evaluated months (Table 2).

\begin{tabular}{ccccc}
$\begin{array}{l}\text { Table 2. } \\
\left(3700 \mathrm{~cm}^{-1}-3000 \mathrm{~cm}^{-1}\right) \text {. }\end{array}$ & & & \\
\hline P Value - Months & H1 x S & H2 x S & H3 x S & H4 x S \\
\hline Sep - 2019 & $0.0000^{*}$ & $0.0000^{*}$ & $0.0000^{*}$ & $0.0000^{*}$ \\
Oct - 2019 & $0.0038^{*}$ & $0.0000^{*}$ & $0.0000^{*}$ & $0.0000^{*}$ \\
Nov - 2019 & $0.0000^{*}$ & $0.0056^{*}$ & $0.0002^{*}$ & $0.0439^{*}$ \\
Dec - 2019 & $0.0000^{*}$ & $0.0000^{*}$ & $0.0000^{*}$ & $0.0000^{*}$ \\
Jan - 2020 & 0.4557 & $0.0000^{*}$ & $0.0005^{*}$ & 0.0861 \\
Feb- 2020 & 0.3490 & $0.0001^{*}$ & $0.0071^{*}$ & $0.0000^{*}$ \\
Mar - 2020 & $0.0000^{*}$ & $0.0000^{*}$ & $0.0000^{*}$ & $0.0000^{*}$ \\
Apr - 2020 & $0.0000^{*}$ & 0.7984 & $0.0009^{*}$ & $0.0001^{*}$ \\
May - 2020 & 0.8919 & 0.9623 & $0.0303^{*}$ & $0.0000^{*}$ \\
Jun - 2020 & $0.0000^{*}$ & $0.0001^{*}$ & $0.0003^{*}$ & $0.0006^{*}$ \\
Jul - 2020 & $0.0000^{*}$ & $0.0000^{*}$ & $0.0000^{*}$ & $0.0000^{*}$ \\
Aug - 2020 & 0.4240 & $0.0000^{*}$ & 0.4643 & $0.0204^{*}$ \\
Sep - 2020 & $0.0008^{*}$ & $0.0000^{*}$ & $0.0020^{*}$ & 0.8100 \\
\hline
\end{tabular}

*0.05 Significance.

The data obtained demonstrate that the water absorption range in the spectra differ significantly $(\mathrm{p}<0,05)$ between hydrogel and control treatments, with few exceptions. Plants react to the influence of external factors such as water soil disponibility and air condition and the quantitative response can be obtained by spectroscopic techniques assessment (Buitrago et al., 2016; Depciuch et al., 2017). Therefore, the results suggest that hydrogel use provides significant changes in the Rapanea ferruginea mid-infrared (FTIR) water-band absorption, which also influences the biomolecular bands.

\subsection{Spectra Analysis}

The Rapanea ferruginea spectra showed good reproducibility in all treatments. Figure 3 shows the average and the standard deviation (SD) of the groups H1, H2, H3, H4 and S.

The precision was evaluated by repeatability. The precision is influenced by the experimental error and it can be estimated by the standard deviations (SD). The FTIR spectra of Rapanea ferruginea leaf showed good repeatability with low standard deviation in the region 
of the biomolecules (Figure 3). The fingerprint region has a low standard deviation, so the data show a good precision.
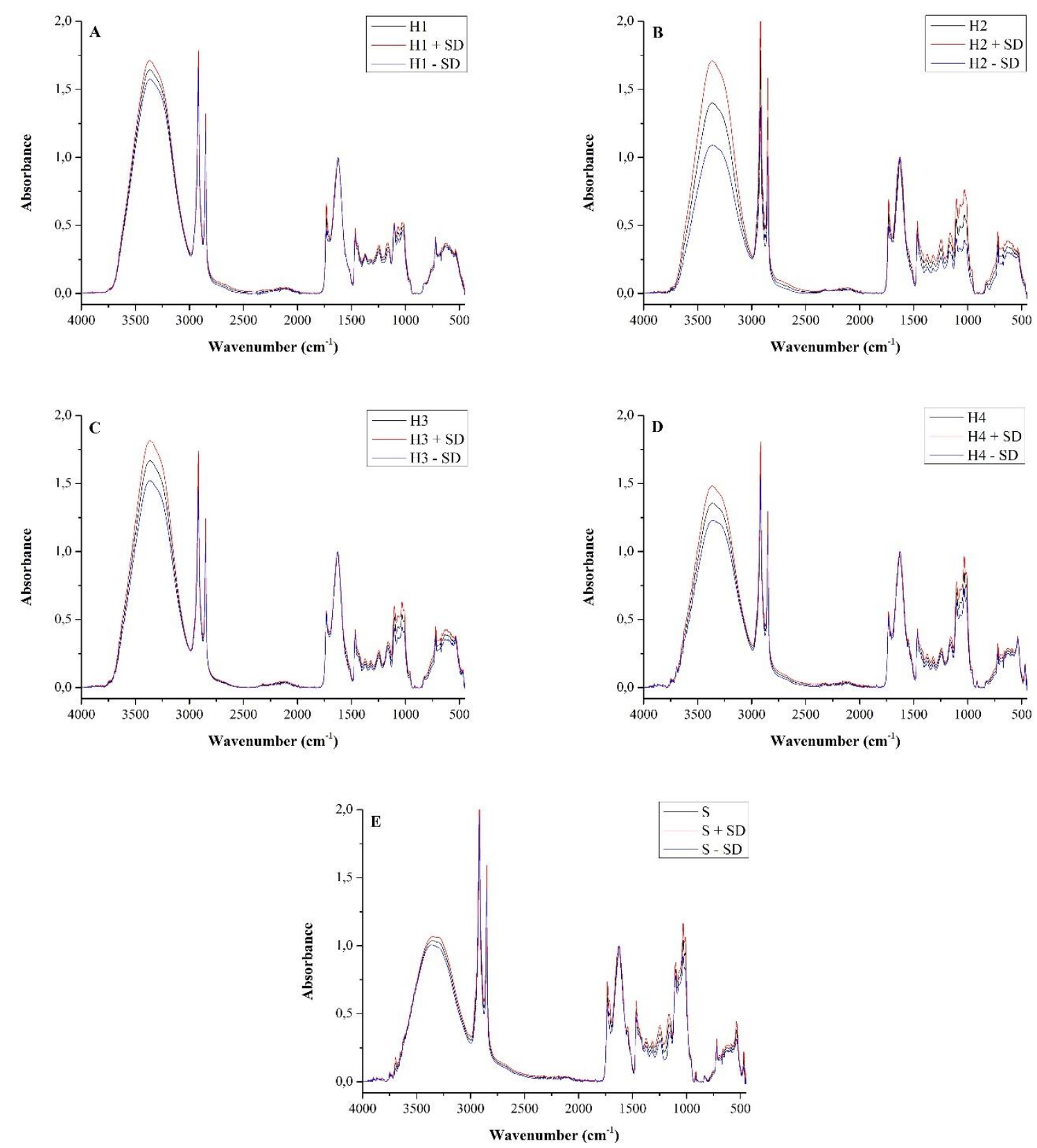

Figure 3. Average spectra and deviations. A-H1 (25\%); B-H2 (20\%); C-H3 (15\%); D-H4 (10\%); E- (Control).

Infrared spectrum bands that were assessed using HCA and PCA analysis and the respective approximate assignments are shown in Table 3.

It was possible to note some differences between the treatments by visual inspection of the spectra. Hydrogel use improves the plant water-retention capacity (Larcher, 2000). The spectra results indicated a clear positive impact on the water correspondent band $\left(3700 \mathrm{~cm}^{-1}\right.$ $3000 \mathrm{~cm}^{-1}$ ) in all hydrogel samples (Figure 3A to 3D) compared to the control group (Figure $3 \mathrm{E})$. The water band was more intense on the samples with $15 \%(\mathrm{H} 3), 25 \%(\mathrm{H} 1)$ and $20 \%(\mathrm{H} 2)$ of hydrogel. H4 (10\%) had better response than the control (S), but the intensity was inferior to the other hydrogel samples. The numbered bands of Table 3 are indicated in Figure 4. 
Table 3. FTIR spectrum bands evaluated and approximate assignments of Rapanea ferruginea.

\begin{tabular}{|c|c|c|c|c|}
\hline $\mathbf{N}^{\mathbf{o}}$ & $\begin{array}{l}\text { Frequency Range } \\
\qquad\left(\mathrm{cm}^{-1}\right)\end{array}$ & $\begin{array}{l}\text { Approximate } \\
\text { Assignments }\end{array}$ & Components & References \\
\hline 1 & $3700-3000$ & $\mathrm{v}$ of $\mathrm{O}-\mathrm{H}$ bond & Water & $\begin{array}{l}\text { Gorgulu et al. (2007); Depciuch } \\
\text { et al. }(2017)\end{array}$ \\
\hline 2 & $3000-2800$ & $\begin{array}{l}v_{\text {asy }} \text { of } \mathrm{C}-\mathrm{H} \text { bond in }-\mathrm{CH}_{2} \\
\text { group } \\
v_{\text {sy }} \text { of } \mathrm{C}-\mathrm{H} \text { bond in }-\mathrm{CH}_{2} \\
\text { group }\end{array}$ & Lipids & $\begin{array}{l}\text { Gorgulu et al. (2007); Depciuch } \\
\text { et al. }(2017)\end{array}$ \\
\hline 3 & $1770-1693$ & $\begin{array}{l}v \text { of } \mathrm{C}=\mathrm{O} \text { bond in ester } \\
\text { group }\end{array}$ & Pectin & $\begin{array}{l}\text { Gorgulu et al. (2007); Sato et al. } \\
\text { (2011) }\end{array}$ \\
\hline$*$ & $1693-1486$ & $v$ of aromatic ring & Amide I (Protein) & $\begin{array}{l}\text { Gorgulu et al. (2007); Dokken } \\
\text { and Davis (2007) }\end{array}$ \\
\hline 4 & $1486-1400$ & $\begin{array}{l}\delta_{\text {asy }} \text { of } \mathrm{C}-\mathrm{H} \text { bond in }-\mathrm{CH}_{3} \\
\text { group } \\
\delta_{\text {sy }} \text { of } \mathrm{C}-\mathrm{H} \text { bond in }-\mathrm{CH}_{2} \\
\text { group }\end{array}$ & $\begin{array}{l}\text { Cell Wall } \\
\text { (Cellulose) }\end{array}$ & $\begin{array}{l}\text { Dokken and Davis (2007); } \\
\text { Depciuch et al. (2017) }\end{array}$ \\
\hline 5 & $1290-1200$ & $\begin{array}{l}v \text { of } \mathrm{C}-\mathrm{N} \text { bond; } \delta \text { of } \mathrm{N}-\mathrm{H} \\
\text { bond }\end{array}$ & Hemicellulose & $\begin{array}{l}\text { Gorgulu et al. (2007); Depciuch } \\
\text { et al. }(2017)\end{array}$ \\
\hline 6 & $1200-1128$ & $\begin{array}{l}\mathrm{v}_{\text {asy }} \text { of } \mathrm{C}-\mathrm{O} \text { bond in - } \\
\mathrm{COOH} \text { group }\end{array}$ & Chlorophyll & Luz (2005) \\
\hline 7 & $1128-1084$ & $v$ of $\mathrm{C}-\mathrm{O}$ bond & Starch & $\begin{array}{l}\text { Thumanu et al. (2015); } \\
\text { Depciuch et al. (2017) }\end{array}$ \\
\hline 8 & $735-700$ & $\begin{array}{l}\delta_{\text {asy }} \text { of }-\mathrm{CH}_{2} \text { bond - } \\
\text { "rocking" }\end{array}$ & Lignin & Dokken and Davis (2007) \\
\hline
\end{tabular}

$*_{v}$ : Stretching. $v_{\text {sy }}$ : Symmetric stretching. $v_{\text {asy }}$ : Asymmetric stretching. $\delta$ : Bending. $\delta_{\text {sy }}:$ Symmetric bending. $\delta_{\text {asy }}$ : Asymmetric bending.

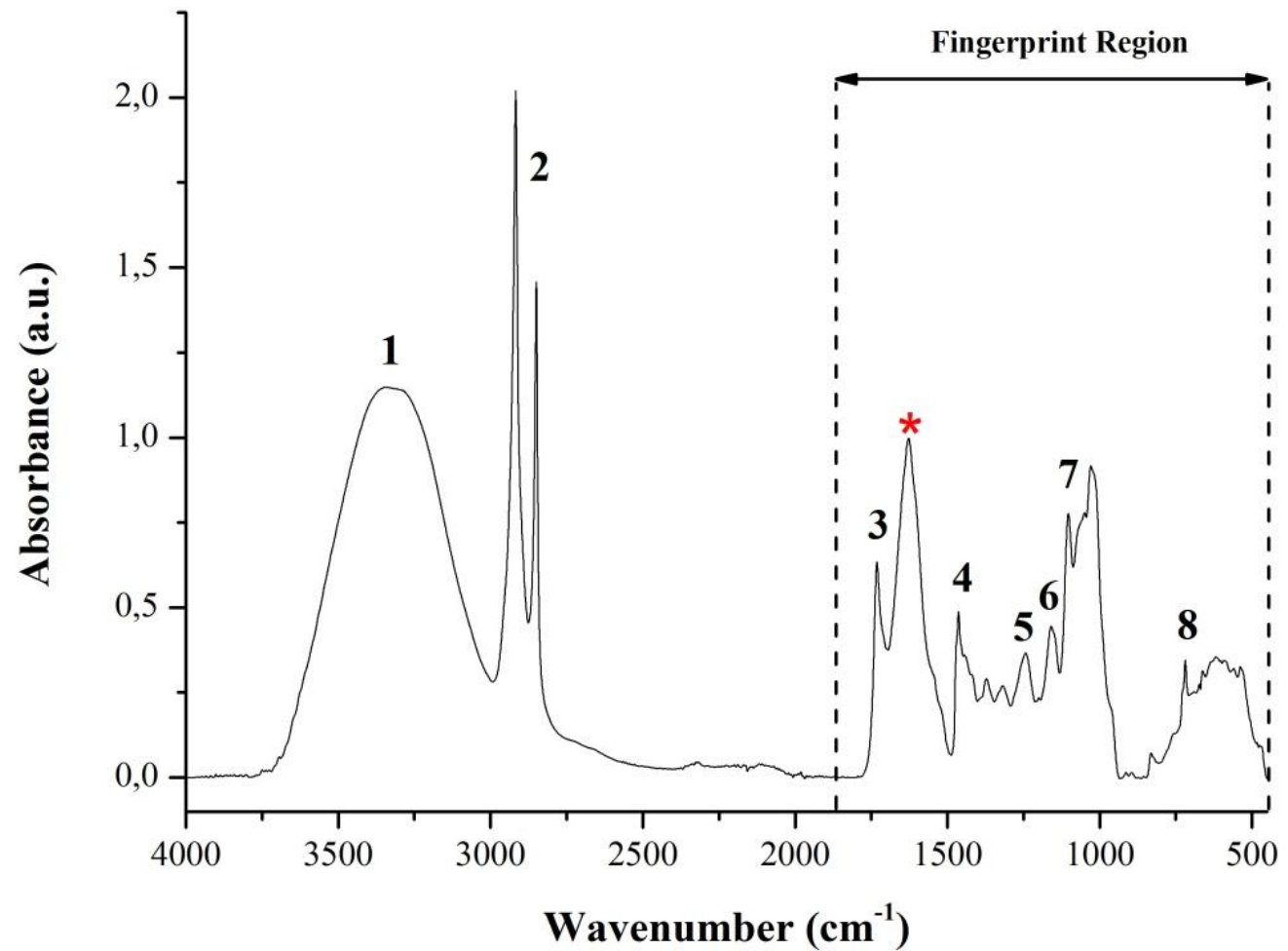

Figure 4. Rapanea ferruginea spectrum with its band approximate assignments. 
In Figure 4 the bands which were used for the PCA and HCA analysis are indicated. The red asterisk marks the protein band also called Amide I that was defined as the normalization band for all spectra obtained (Berthomieu and Hienerwadel, 2009).

The data in Table 3 shows that the FTIR method has adequate accuracy, since the observed wavenumbers are very close to the reference values found in the literature. Certain atom groups are able to produce the bands at near the same wavenumber in different molecules and the structural information is obtained by these characteristic bands presented in the literature (Silverstein et al., 2006).

The robustness was evaluated by the small modifications in the method parameter. The small variations, especially leaf thickness and time compression, did not alter the characteristic bands region. Therefore, no effect of the leaves on the spectra was reported. The FTIR technique provides accuracy compared to other methods and helps in the detection of impurities (Farouk et al., 2011).

\subsection{Hierarchical Clustering (HCA) and Principal Component (PCA) Analysis}

Evaluation by infrared FTIR spectroscopy produces a large amount of data which demands assessment by statistical techniques. Principal Component Analysis (PCA) is a technique that allows matrix data set reduction to the smallest orthogonal matrix through covariance relations or data correlation (Bro and Smilde, 2014). PCA use associated with hierarchical cluster analysis (HCA) allows the classification of variables into groups according to the statistical components' similarities (Dos Santos Grasel et al., 2016).

The associated use of PCA and HCA to evaluate extensive databases is a powerful statistical analysis technique. Therefore, using the normalized ATR-FTIR spectra as chemical descriptors, cluster analysis and principal component analysis were applied in order to observe the biochemical changes in the Rapanea ferruginea by the hydrogel-use influence.

Hierarchical clustering analysis (HCA) was applied differentiating the data by covariance with adoption of Ward's agglomerative method to establish clusters and Euclidean distance to calculate dissimilarity coefficients. The spectra band ranges submitted to HCA and PCA analysis were the region of lipids $\left(3000 \mathrm{~cm}^{-1}-2800 \mathrm{~cm}^{-1}\right)$ and fingerprint components $\left(1770 \mathrm{~cm}^{-1}-700 \mathrm{~cm}^{-1}\right)$ where the evaluated biomolecules are located (Pectin, Protein, Cell Wall (Cellulose), Hemicellulose, Chlorophyll, Starch and Lignin). Figure 5 shows the result of the HCA analysis, where two main clusters can be seen, corresponding to Rapanea ferruginea seedlings with $(\mathrm{H})$ and without hydrogel $(\mathrm{S})$.

HCA analysis of seedlings with $25 \%$ hydrogel - H1 in relation to the control group (S) indicated a statistically significant difference (Figure 5A). The hydrogel specimens (1,2 and 3) formed a homogeneous group separate from the control seedlings (4, 5 and 6). Seedlings 1 and 2 showed a $71.91 \%$ similarity and both resembled $50.59 \%$ to specimen 3 , results that suggest a greater similarity between seedlings cultivated with hydrogel. Among seedlings without hydrogel, specimens 4 and 5 showed similarity of $72.46 \%$; however, specimen 6 did not show significant similarity to the other specimens, indicating greater dispersion.

In the treatment with $20 \%$ hydrogel - H2 (Figure 5B) - there was also separation in independent cluster groups, however, with less homogeneity compared to H1. The samples with hydrogel 1 and 2 were $49.81 \%$ similar, while specimen 3 showed low similarity $(6.06 \%)$. The control group (4, 5 and 6) showed greater similarity between the specimens $(60 \%)$. Despite the lower statistical similarity, the results suggest that the use of $20 \%$ of hydrogel in the crop provides changes in the structure of Rapanea ferruginea that can be observed by mid-infrared spectra submitted to HCA analysis.

The group cultivated with $15 \%$ hydrogel - H3 (Figure 5C) showed a significant difference to the control group. Specimens 2 and 3 were similar at $71.51 \%$, while seedling 1 was similar at $53.76 \%$, suggesting a greater homogeneity similar to H1. In the control, seedlings 5 and 
6 were similar to $71.30 \%$, and specimen 4 showed similarity with low significance, indicating greater dispersion in the control group. The results suggest that the amount of $15 \%$ hydrogel provides changes in the structural biomolecules of Rapanea ferruginea. FTIR evaluation allows observing physiological changes in plants after the influence of external environmental factors (Depciuch et al., 2017; Lins, 2017).

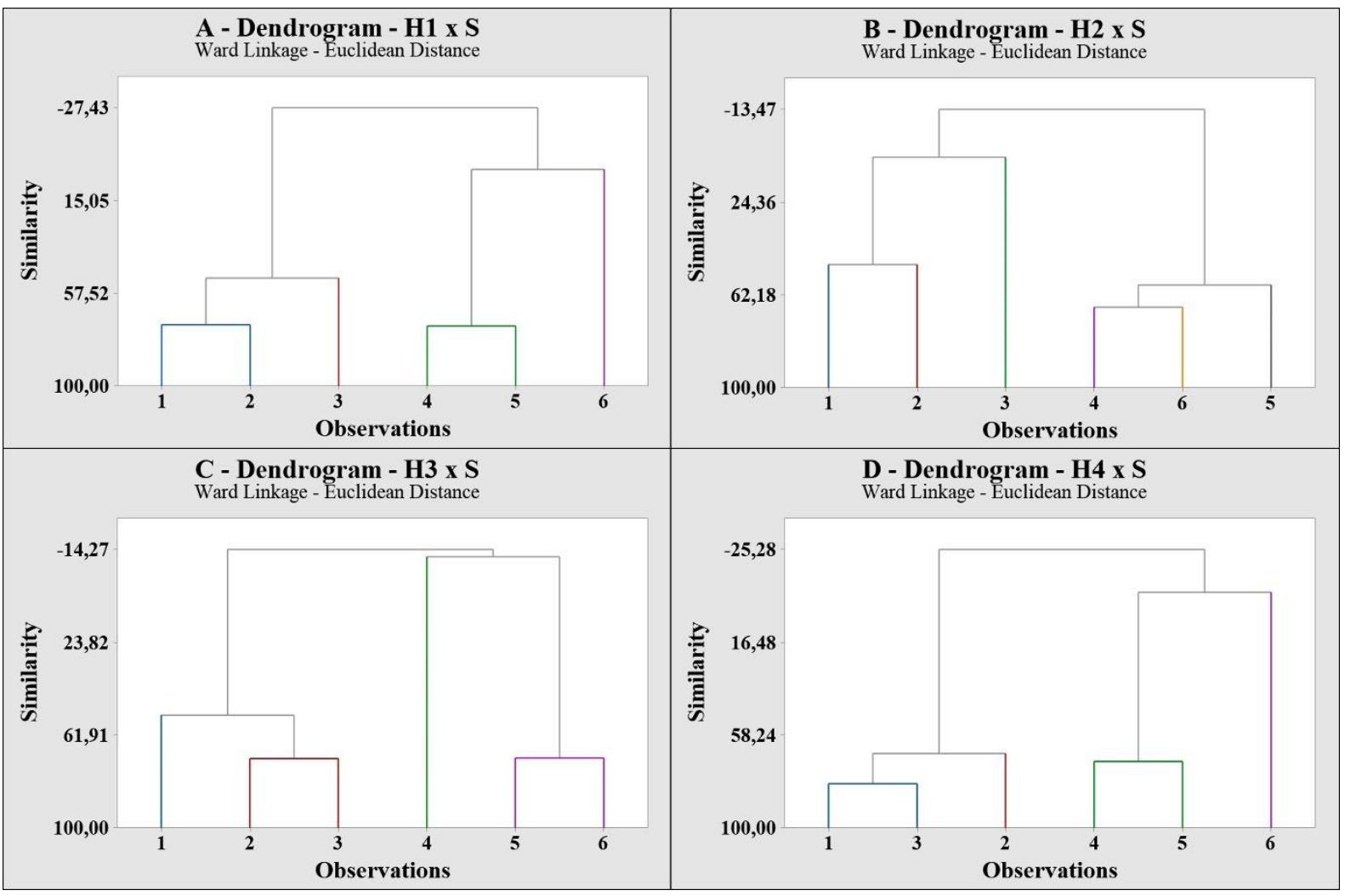

Figure 5. Dendrograms - HCA analysis. A- H1 x S; B- H2 x S; C-H3 x S; D- H4 x S.

The seedlings of the group cultivated with $10 \%$ hydrogel (Figure 5D) showed the best similarity homogeneity among all treatments evaluated. Also, both groups split into independent clusters. Seedlings 1 and 3 were $80.11 \%$ structurally similar and both showed a $66.55 \%$ similarity in relation to specimen 2 . Among the control specimens, seedlings 4 and 5 resembled $70.09 \%$ and specimen 6 showed little significant similarity compared to the others. The use of hydrogel in conditions of water restriction provides better plant development (Larcher, 2000). External environmental factors can be quantified by FTIR spectroscopy analysis (Depciuch et al., 2017).

Score scatter plot obtained by the principal component analysis (PCA) of the FTIR spectra after baseline correction and normalization is displayed in Figure 6. The results showed a level of discrimination between the hydrogel cultivated seedlings in relation to the control ones. Sample grouping can be observed with some overlapping between two groups. For each group, the first two components accounted for more than $95 \%$ of the total sample variance as shown in the details of Table 4.

Each point in the score plot represents a triplicate spectra for each seedling. The results suggest a clear tendency of separation between the hydrogel treatments in relation to the control seedlings. It also can be noticed that the dispersion of the score plot was greater in the control group (S). The hydrogel use permits a homogeneous growth in Rapanea ferruginea seedlings which reflects on the PCA results. Among the hydrogel treatments, H3 (15\%) and H4 (10\%) (Figure 6C and 6D) showed the best score plot groupings. Substrate conditions and water retention affect the plant development and the results are reflected in the biomolecular FTIR 
fingerprint (Palacio et al., 2014).

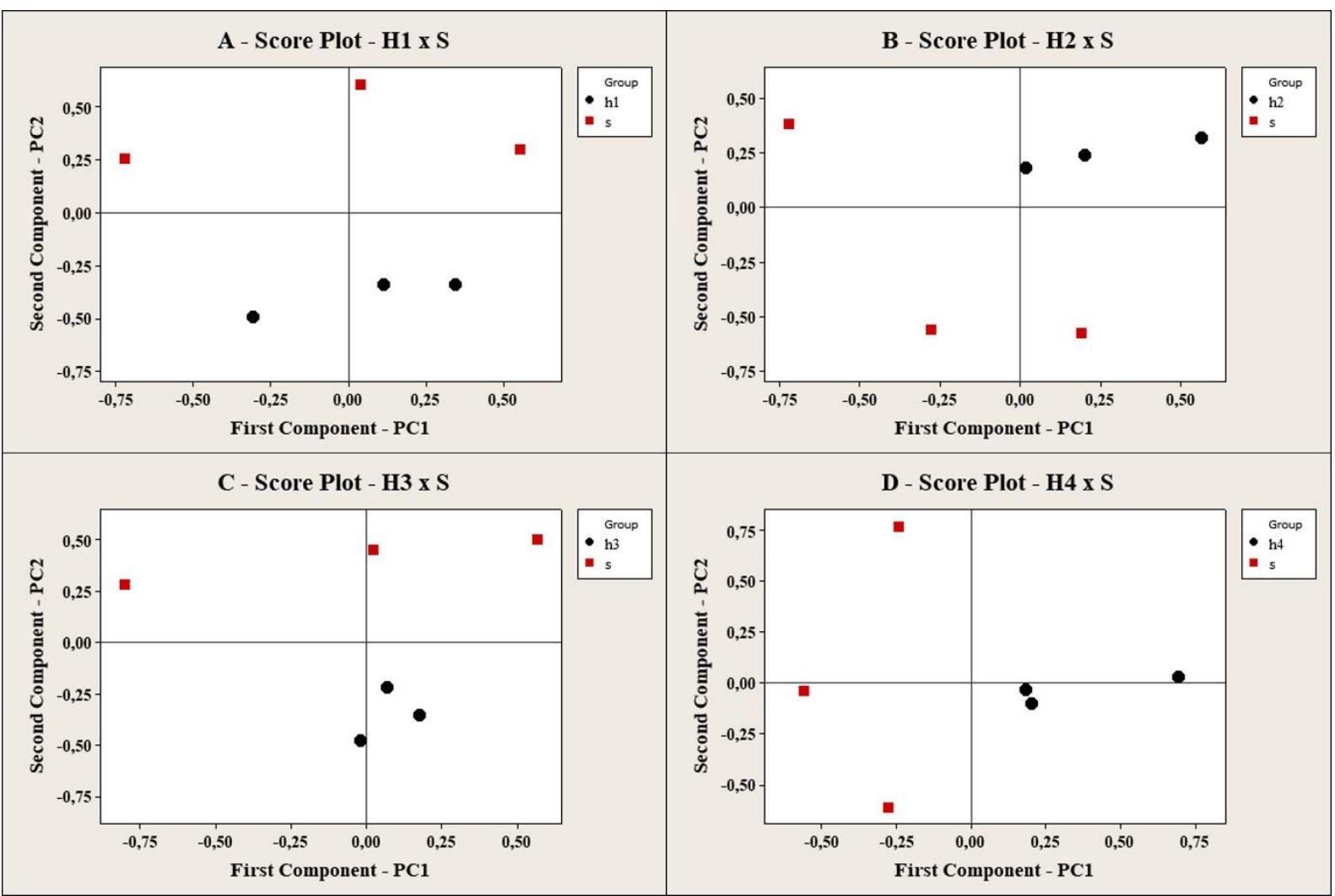

Figure 6. Score Plots - PCA Analysis. A - H1 x S; B - H2 x S; C - H3 x S; D - H4 x S.

Table 4. PC1 and PC2 percentage contribution in the PCA of Rapanea ferruginea.

\begin{tabular}{ccc}
\hline Treatments & PC1 (\%) & PC2 (\%) \\
\hline H1 x S & 98.2 & 1.4 \\
H2 x S & 96.3 & 3.1 \\
H3 x S & 98.3 & 1.0 \\
H4 x S & 97.6 & 1.9 \\
\hline
\end{tabular}

The results indicate that the use of hydrogel in the cultivation of Rapanea ferruginea provides changes in water absorption that reflect changes in the biomolecular structure. These changes are observable through Fourier Transform Infrared Spectroscopy (FTIR) analysis. Therefore, FTIR is feasible for monitoring the influence of water absorption capacity in high plant biomolecular development. In general, all treatments showed a significant difference in relation to the control. The cultivation with $20 \%$ hydrogel $(\mathrm{H} 2)$ presented the best correlations between the biomolecular components and the water band and $10 \%$ hydrogel $(\mathrm{H} 4)$ and $15 \%$ hydrogel groups showed greater similarity in the evaluation by HCA and PCA analysis.

\section{CONCLUSION}

The use of hydrogel provides greater retention to vegetables in conditions of water 
restriction that directly reflects in the physiological conditions of Rapanea ferruginea. Internal plant changes influenced by hydrogel use can be monitored with the Fourier Transform Infrared Spectroscopy (FTIR).

The results suggest a positive influence of hydrogel use on the hydroxyl stretch band that indicates the presence of water in the plant in the FTIR. There was a high correlation between this band and the lipid, hemicellulose, starch and cell wall (cellulose) bands. The treatment with $20 \%$ hydrogel showed the best correlation, the results suggest that the aforementioned bands are ideal for monitoring the influence of the hydrogel on internal Rapanea ferruginea development.

The evaluation of the water band by the Mann-Whitney test indicated a significant difference $(\mathrm{p}<0.05)$ between the hydrogel treatments and the control group in the total monitoring period. The influence of the hydrogel was also observed in the evaluation of the biomolecules by HCA and PCA analysis. The results demonstrate a significant difference between the groups treated with hydrogel in relation to the control. The groups with $10 \%$ and $15 \%$ hydrogel showed the most significant difference in HCA and PCA, an important result to define the optimal value of hydrogel application for the species.

Therefore, the present study suggests that the use of hydrogels for cultivation in water restriction conditions allows for better water retention in the soil, which consequently benefits plant leaf and root development and promotes structural and functional biomolecule growth.

\section{ACKNOWLEDGMENTS}

The author is grateful for the support of the Granado Institute of Polyacrylonitrile Technology (IGTPAN), in the granting of the master's scholarship.

The authors would like to thank FAPESP for supporting the acquisition of PerkinElmer's Spectrum Two spectrophotometer by Process 2017/04013-0.

\section{REFERENCES}

BERTHOMIEU, C.; HIENERWADEL, R. Fourier transform infrared (FTIR) spectroscopy. Photosynthesis Research, v. 101, p. 157-170, 2009. https://dx.doi.org/10.1007/s11120009-9439-x

BOGARIM, E. P. de A. Uso de Hidrogel do Desenvolvimento de Espécies Nativas, Visando Aplicação em Áreas Degradadas. 2014. 62 f. Dissertação (Mestrado em Ciência e Tecnologia Ambiental) - Universidade Federal da Grande Dourados, Dourados, 2014.

BRO, R.; SMILDE, A. K. Principal component analysis. Analytical Methods, v. 6, n. 9, p. 2812-2831, 2014. https://doi.org/10.1039/C3AY41907J

BUITRAGO, M. F. et al. Changes in thermal infrared spectra of plants caused by temperature and water stress. ISPRS journal of photogrammetry and remote sensing, v. 111, p. 22-31, 2016. http://dx.doi.org/10.1016/j.isprsjprs.2015.11.003

BUITRAGO, M. F. et al. Connecting infrared spectra with plant traits to identify species. ISPRS journal of photogrammetry and remote sensing, v. 139, p. 183-200, 2018. https://doi.org/10.1016/j.isprsjprs.2018.03.013

CARDOSO, R. R. Efeito da incorporação de hidrogel em substratos na produção de mudas de jatobá-da-mata (Hymenaea courbaril Lee \& Lang) e jatobá-do-cerrado (Hymenaea stigonocarpa Mart.). 2017. Trabalho de Conclusão (Engenharia Florestal) Universidade de Brasília, Brasília, 2017. 
CHEN, X. et al. Degradation degree analysis of environmental microplastics by micro FT-IR imaging technology. Chemosphere, v. 274, p. 129779, 2021. http://doi.org/10.1016/j.chemoshere.2021.129779

DEPCIUCH, J. et al. FTIR analysis of molecular composition changes in hazel pollen from unpolluted and urbanized areas. Aerobiologia, v. 33, n. 1, p. 1-12, 2017. https://doi.org/10.1007/s10453-016-9445-3

DOKKEN, K. M.; DAVIS, L. C. Infrared imaging of sunflower and maize root anatomy. Journal of agricultural and food chemistry, v. 55, n. 26, p.10517-10530, 2007. https://doi.org/10.1021/jf072052e

DOS SANTOS GRASEL, F. et al. Development of methodology for identification the nature of the polyphenolic extracts by FTIR associated with multivariate analysis. Spectrochimica Acta Part A: Molecular and Biomolecular Spectroscopy, v. 153, p. 94-101, 2016. https://doi.org/10.1016/j.saa.2015.08.020

DURAK, T.; DEPCIUCH, J. Effect of plant sample preparation and measuring methods on ATR-FTIR spectra results. Environmental and Experimental Botany, v. 169, p. 103915, 2020. https://doi.org/10.1016/j.envexpbot.2019.103915

DURAZZO, A. et al. Qualitative analysis of traditional Italian dishes: FTIR approach. Sustainability, v. 10, n. 11, p. 4112, 2018. http://dx.doi.org/10.3390/su10114112

FAROUK, F. et al. Fourier transform infrared spectroscopy for in-process inspection, counterfeit detection and quality control of anti-diabetic drugs. Spectroscopy, v. 26, n. 4-5, p. 297-309, 2011. http://dx.doi.org/10.3233/SPE-2011-0531

FELIPPE, D. et al. Hydrogel in the seedling growth of Eucalyptus dunnii Maiden under different irrigation management. Revista Ambiente \& Água, v. 16, n. 1, 2021. http://dx.doi.org/10.4136/1980-993X

FERRAZ, A. de V.; ENGEL, V. L. Efeito do tamanho de tubetes na qualidade de mudas de Jatobá (Hymenaea courbaril L.VAR. stilbocarpa (HAYNE) LEE ET LANG.), IpêAmarelo (Tabebuia chrysotricha (MART. EX DC.) SANDL.) e Guarucaia (Parapiptadenia rigida (BRENTH.) BRENAN). Revista Árvore, v. 35, n. 3, p. 413-423, 2011. https://doi.org/10.1590/S0100-67622011000300005

FRAGOSO, R. de O. et al. Recuperação de área degradada no domínio floresta estacional semidecidual sob diferentes tratamentos. Ciência Florestal, v. 26, n. 3, p. 699-711, 2016. http://dx.doi.org/10.5902/1980509824194

GALLARDO-VELÁZQUEZ, T. et al. Application of FTIR-HATR spectroscopy and multivariate analysis to the quantification of adulterants in Mexican honeys. Food $\begin{array}{llllllll}\text { Research International, } & \text { v. } 42, \quad \text { n. } 3, \quad \text { p. 313-318, } 2009 .\end{array}$ http://dx.doi.org/10.1016/j.foodres.2008.11.010

GORGULU, S. T. et al. The Characterization and Differentiation of Higher Plants by Fourier Transform Infrared Spectroscopy. Applied Spectroscopy, v.61, n.3, p. 300-308, 2007. http://dx.doi.org/10.1366/000370207780220903

GÜLER, G. et al. Deciphering the biochemical similarities and differences among mouse embryonic stem cells, somatic and cancer cells using ATR-FTIR spectroscopy. Analyst, v. 143, n. 7, p. 1624-1634, 2018. https://doi.org/10.1039/c8an00017d 
HELLER, C. et al. Soil organic matter characterization of temperate peatland soil with FTIRspectroscopy: effects of mire type and drainage intensity. European Journal of Soil Science, v. 66, p. 847-858, 2015. http://dx.doi.org/10.1111/ejss.12279

IOAKEIMIDIS, C. et al. The degradation potential of PET bottles in the marine environment: An ATR-FTIR based approach. Scientific reports, v. 6, n. 1, p. 1-8, 2016. http://dx.doi.org/10.1038/srep23501

KASIM, N. E. et al. Using Infrared Absorption Spectroscopy in Studying Nitrogen,

Chlorophyll and Starch Contents in Manzenillo Olive Leaves Before Harvest Stage. World Applied Sciences Journal, v. 31, n. 7, p. 1337-1340, 2014. http://dx.doi.org/10.5829/idosi.wasj.2014.31.07.14437

KOCHAN, K. et al. Infrared Spectroscopy of Blood. Applied Spectroscopy, v. 75, n. 6, p. 611-646, 2021. http://dx.doi.org/10.1177/0003702820985856

KOUPAI, J.A. et al. Enhancing the available water content in unsaturated soil zone using hydrogel, to improve plant growth indices. Ecohydrology \& Hydrobiology, v.8, n.1, p.67-75, 2008. http://dx.doi.org/10.2478/v10104-009-0005-0

LARCHER, W. Ecofisiologia vegetal. 1. ed. São Carlos: RiMA, 2000. 531 p.

LARSON, R.; FABER, B. Estatística aplicada. São Paulo: Prentice Hall, 2010. 672 p.

LINARES-GABRIEL, A. et al. Application of soil amendments and their effect in the growth of heliconia. Ornamental Horticulture, v. 24, n. 3, p.249-254, 2018. http://dx.doi.org/10.14295/oh.v24i3.1252

LINS, E. F. Estudo das respostas fisiológicas de essências florestais nativas de Rapanea ferruginea submetidas a diferentes faixas de radiação solar por espectroscopia no infravermelho com transformada de Fourier (FTIR-ATR). 2017. 57 f. Dissertação (Mestrado em Bioengenharia) - Instituto de Pesquisa e Desenvolvimento, Universidade do Vale do Paraíba, Jacareí, 2017.

LORENZI, H. Árvores brasileiras: manual de identificação e cultivo de plantas arbóreas nativas do brasil. 5. ed. Nova Odessa: Instituto Plantarum, 2008. v. 1. 385 p.

LUCARINI, M. et al. Grape seeds: Chromatographic profile of fatty acids and phenolic compounds and qualitative analysis by FTIR-ATR spectroscopy. Foods, v. 9, n. 1, p. 10, 2020. http:// http://dx.doi.org/10.3390/foods 9010010

LUZ, B. R. da. Propriedades espectrais das plantas no infravermelho termal (2,5 - $14 \mu \mathrm{m})$ : da química ao dossel. 2005. 188 p. Tese (Doutorado) - Curso de Ciências na área de ecologia: sistemas aquáticos e terrestres, Universidade de São Paulo, São Paulo, 2005.

MEWS, C. L. et al. Efeito do Hidrogel e Ureia na Produção de Mudas de Handroanthus ochraceus (Cham.) Mattos. Floresta e Ambiente, v. 22, n. 1, p. 107-116, 2015. http://dx.doi.org/10.1590/2179-8087.080814

MIHOUBI, W. et al. FTIR spectroscopy of whole cells for the monitoring of yeast apoptosis mediated by p53 over-expression and its suppression by Nigella sativa extracts. PLoS One, v. 12, n. 7, p. e0180680, 2017. https://doi.org/10.1371/journal.pone.0180680

MUDHANGANYI, A. et al. The influence of hydrogel soil amendment on the survival and growth of newly transplanted Pinus patula seedlings. Journal of Forestry Research, v. 29, n. 1, p. 103-109, 2016. http://dx.doi.org/10.1007/s11676-017-0428-1 
NAVROSKI, M. C. et al. Influência do Polímero Hidroretentor nas Características do Substrato Comercial para Produção de Mudas Florestais. Interciencia, v. 41, n. 5, p. 357-361, 2016.

PALACIO, S. et al. Gypsophile Chemistry Unveiled: Fourier Transform Infrared (FTIR) Spectroscopy Provides New Insight into Plant Adaptations to Gypsum Soils. PLOS ONE, v. 9, n. 9, p. 1-13, 2014. https://doi.org/10.1371/journal.pone.0107285

PASCOTTO, M. C. Rapanea ferruginea (Ruiz \& Pav.) Mez. (Myrsinaceae) como uma importante fonte alimentar para as aves em uma mata de galeria no interior do Estado de São Paulo. Revista Brasileira de Zoologia, v. 3, n. 24, p. 735-741, 2007. https://doi.org/10.1590/S0101-81752007000300026

PAVIA, D. L. et al. Introdução à espectroscopia. Cengage Learning, 2010. 708 p.

RAMIREZ, A. et al. Materiales polimeros de tipo hidrogeles: revisión sobre su caracterización mediante ftir, dsc, meb y met. Revista Latinoamericana de Metalurgia y Materiales, v. 36, n. 2, p. 108-130, 2016.

SAKANE, K. K. et al. Biochemical changes in Leishmania braziliensis after photodynamic therapy with methylene blue assessed by the Fourier transform infrared spectroscopy. Lasers in Medical Science, v. 36, n. 4, p. 821-827, 2021. http://dx.doi.org/10.1007/s10103-020-03110-2

SARVAS, M. et al. Effect of hydrogel application on survival and growth of pine seedlings in reclamations. Journal of Forest Science, v. 53, n. 5, p. 204-209, 2007. http://dx.doi.org/10.17221/2178-JFS

SATO, M. de F. et al. Chemical and instrumental characterization of pectin from dried pomace of eleven apple cultivars. Acta Scientiarum. Agronomy, n. 33, v. 3, p.383-389, 2011. http://dx.doi.org/10.4025/actasciagron.v33i3.7125

SILVERSTEIN, R. M.; WEBSTER, F. X.; KIEMLE, D. J. Identificação espectrométrica de compostos orgânicos. 7. ed. Ltc, 2006. 508 p.

SLOAN, J. P. The Use of Rootdips on North American Conifer Seedlings: A Review of the Literature. The Planter's Notes, v. 45, n. 1, p. 26-31, 1994.

SOUSA, G. T. O. et al. Incorporação de polímero hidroretentor no substrato de produção de mudas de Anadenanthera peregrina (L.) SPEG. Enciclopédia Biosfera, v. 9, n. 16, p. 1270-1278. 2013.

STUART, B. Infrared Spectroscopy: Fundamentals and Applications. 1th. ed. Chichester: John Wiley \& Sons, 2004. 242 p.

THUMANU, K. et al. Use of infrared microspectroscopy to determine leaf biochemical composition of cassava in response to Bacillus subtilis CaSUT007. Journal of Plant $\begin{array}{lllllll}\text { Interactions, } & \text { v. } & 10, & \text { n. } & 1, & \text { p. } & 270-279,\end{array}$ https://doi.org/10.1080/17429145.2015.1059957

VIEIRA, C. A. G. A. et al. Infrared Spectroscopy based Study of Biochemical Changes in Saliva During Maximal Progressive Test in Athletes. Analytical Sciences, p. 20P395, 2021. https://doi.org/10.2116/analsci.20P395 